\title{
Neurointerventional therapy for large vessel occlusion stroke: the new standard of care
}

\author{
Pavis Laengvejkal MD, Doungporn Ruthirago MD, Parunyou Julayanont MD, and Yazan Alderazi MD
}

For the past two decades, intravenous tissue plasminogen activator (IV tPA) has been the gold standard treatment of acute ischemic stroke (AIS) for patients presenting to the hospital in the first 4.5 hours after symptom onset. However, in patients with AIS due to intracranial large vessel occlusion (LVO), IV tPA has very poor recanalization rates. This group of patients has significantly worse outcomes than those without LVO. Endovascular therapy has evolved significantly since the first trial in 1998. With the publication of recent trials using modern stent-retriever devices and selection of patients with LVO, endovascular therapy has become the standard of care for patients with the most severe ischemic strokes. In this article we outline the two decade evolution of this therapy.

\section{FIRST GENERATION ENDOVASCULAR TRIALS}

In an attempt to increase recanalization rates in AIS patients, the first randomized controlled trial (RCT) using intra-arterial thrombolysis (pro-urokinase), Prolyse in Acute Cerebral Thromboembolism (PROACT), was completed in $1998 .{ }^{1}$ This study showed superiority in recanalization in acute LVO stroke compared with placebo but unfortunately also an increased risk of symptomatic hemorrhage. In spite of this initial result, pro-urokinase was taken off of the market.

Corresponding author: Doungporn Ruthirago Contact Information: Doungporn.ruthirago @ttuhsc.edu DOI: $10.12746 / \mathrm{swrccc} 2016.0416 .216$
With the hope for better treatment options, additional trials of endovascular intervention were completed. The interventions included intra-arterial thrombolysis using alteplase tPA and the Merci thrombectomy device. In 2013, three studies were published, "IMS III, MR RESCUE, and SYNTHESIS Expansion”., 2, 3, 4 These three multicenter, prospective RCTs showed no benefit in the intervention arm but also showed no additional risk of symptomatic bleeding after the intervention. Several concerns were raised regarding some aspects of these trials, including non-universal determination of LVO, use of first generation lower-efficacy devices such as the Merci device, the use of intra-arterial tPA without device in some trials (e.g., $66 \%$ of endovascular patients in the SYNTHESIS trial were treated with intra-arterial tPA alone), high utilization of intra-arterial tPA and heparin, and slow randomization to arterial puncture time (Table 1 and Table 2).

While these three trials were being conducted, two additional RCTs, SWIFT and TREVO, examined the efficacy and safety of second generation devices (stent retrievers) compared to first generation devices (Merci). ${ }^{5,6}$ The studies demonstrated significantly better recanalization rates with the new devices without any excess in hemorrhagic complications (Table 3 ). 
Table 1 Strengths and weaknesses of first generation endovascular stroke RCTs

\begin{tabular}{|l|l|}
\hline \multicolumn{1}{|c|}{ Strength } & \multicolumn{1}{c|}{ Weakness } \\
\hline Randomized evaluation & Non-universal determination of LVO \\
\hline Allowed systems for endovascular & Use of first generation lower-efficacy devices e.g. Merci \\
clinical trials to be set up & \\
\hline $\begin{array}{l}\text { Established evidence base for IA } \\
\text { tPA safety profile }\end{array}$ & $\begin{array}{l}\text { IA tPA without device in some trials (e.g., 66\% of endo- } \\
\text { vascular patients) }\end{array}$ \\
\hline & High utilization of IA tPA \& Heparin \\
\hline & Slow randomization to puncture time \\
\hline
\end{tabular}

LVO-Large vessel occlusion, IA- intra-arterial, tPA- tissue plasminogen activator

Table 2 First generation endovascular RCTs

\begin{tabular}{|c|c|c|c|c|c|c|}
\hline Study & $\begin{array}{l}\text { Window/ } \\
\text { Eligibility } \\
\text { feature }\end{array}$ & $\begin{array}{c}\text { LVO determi- } \\
\text { nation }\end{array}$ & Intervention & Comparison & Outcome & Result \\
\hline $\begin{array}{c}\text { PROACT } \\
1^{1999^{1}}\end{array}$ & $<6 \mathrm{hr}$ & Yes & IA tPA & IV Heparin & $\begin{array}{c}\mathrm{mRS} \leq 2 \text { at } \\
90 \text { days }\end{array}$ & $\begin{array}{c}\mathrm{n}=180 \\
40 \% \text { vs } 25 \% \quad \mathrm{P}=0.4 \\
\mathrm{sICH} 10 \% \text { vs } 2 \% \quad \mathrm{p}=0.06\end{array}$ \\
\hline $\begin{array}{l}\text { IMS III } \\
2013^{2}\end{array}$ & $\begin{array}{l}<3-4.5 \mathrm{hrs} \\
\text { But IAT in } \\
6 \mathrm{hrs}\end{array}$ & Not universal & $\begin{array}{c}\text { IV tPA + IAT (IA } \\
\text { tPA, Merci) }\end{array}$ & IV tPA & $\begin{array}{c}\mathrm{mRS} \leq 2 \text { at } \\
90 \text { days }\end{array}$ & $\begin{array}{c}\mathrm{n}=656 \\
40.8 \% \text { vs } 38.7 \% \\
\text { CI, }-6.1 \text { to } 9.1 \\
\text { sICH } 6.2 \% \text { vs } 5.9 \%\end{array}$ \\
\hline $\begin{array}{l}\text { MR RES- } \\
\text { CUE } \\
2013^{3}\end{array}$ & $<8 \mathrm{hr}$ & $\begin{array}{l}\text { Yes Anterior } \\
\text { circulation }\end{array}$ & Merci/Penumbra & $\begin{array}{l}\text { Standard care } \\
\text { (IV tPA or } \\
\text { aspirin) }\end{array}$ & $\begin{array}{l}\text { Mean mRS } \\
\text { at } 90 \text { days }\end{array}$ & $\begin{array}{c}\mathrm{n}=118 \\
3.9 \text { vs } 3.9 \text { Mortality } 21 \%, \\
\text { sICH } 4 \% \text { both groups } \\
\text { No interaction: treatment w pen- } \\
\text { umbral pattern }\end{array}$ \\
\hline $\begin{array}{c}\text { SYNTHE- } \\
\text { SIS } \\
2013^{4}\end{array}$ & $\begin{array}{l}<4.5 \mathrm{hr} \text { but } \\
\text { IAT in } 6 \mathrm{hr}\end{array}$ & No & $\begin{array}{l}\text { IAT : (IA tPA full } \\
\text { dose, Merci }+ \\
\text { Heparin } 5000 \mathrm{IU} \\
\text { bolus \& } 500 \mathrm{iu} / \mathrm{hr} \text { ) }\end{array}$ & IV tPA & $\begin{array}{c}\mathrm{mRS} \leq 1 \text { at } \\
90 \text { days }\end{array}$ & $\begin{array}{c}\mathrm{n}=362 \\
30.4 \% \text { vs } 34.8 \% \\
\text { sICH } 6 \% \text { vs } 6 \%\end{array}$ \\
\hline
\end{tabular}

IAT, intra-arterial thrombolysis; LVO, large vessel occlusion; IA tPA, intra-arterial tissue plasminogen activator; IV tPA, intra-venous tissue plasminogen activator; mRS, modified ranking scale; sICH, symptomatic intracerebral hemorrhage 
Table 3 First generation devices versus second generation devices RCTs

\begin{tabular}{|c|c|c|c|c|c|c|}
\hline Study & $\begin{array}{c}\text { Window/ } \\
\text { Eligibility } \\
\text { feature }\end{array}$ & $\begin{array}{l}\text { LVO deter- } \\
\text { mination }\end{array}$ & Intervention & Comparison & Outcome & Result \\
\hline $\begin{array}{l}\text { SWIFT } \\
2012^{5}\end{array}$ & $\begin{array}{c}\text { 8hrs } \\
\text { NIHSS }\end{array}$ & Yes & Solitaire & Merci & TIMI scale $\geq 2$ & $\begin{array}{c}\mathrm{N}=113 \\
61 \% \text { vs } 24 \% \\
\text { OR } 4 \cdot 87(14) ; \\
\mathrm{p}=0 \cdot 0001\end{array}$ \\
\hline $\begin{array}{l}\text { TREVO } \\
2012^{6}\end{array}$ & $\begin{array}{c}\text { 8hrs } \\
\text { NIHSS 8-29 }\end{array}$ & Yes & Trevo & Merci & TICI scale $\geq 2$ & $\begin{array}{c}\mathrm{N}=90 \\
86 \% \text { vs } 60 \% \\
\text { OR } 4 \cdot 22 \\
(12) ; \\
\text { p<0.0001 }\end{array}$ \\
\hline
\end{tabular}

NIHSS- National institute of health stroke scale; LVO- large vessel occlusion; TIMI- thrombolysis in myocardial infarction; TICI- thrombolysis in cerebral infarction

\section{SECOND GENERATION ENDOVASCULAR TRIALS}

Having learned the limitations in the initial studies and with cautious enthusiasm from the device vs. device trials, new endovascular stroke trials were designed and conducted. These second generation RCTs had universal determination of the presence of LVO prior to randomization. Several of the studies initiated optimized workflow protocols to achieve faster randomization to arterial puncture times, and all of the studies used second generation stent-retriever mechanical thrombectomy devices. The first of these, MR CLEAN, was published in late $2014 .^{7}$ This study compared endovascular therapy to best medical treatment in stroke patients with LVO who presented within six hours of symptom onset. Following the presentation of this study at the 2014 World Stroke Congress, multiple endovascular trials were stopped by the respective data safety and monitoring boards due to efficacy of endovascular therapy on interim analysis. The four RCTs (ESCAPE, REVASCAT, EXTEND IA, and SWIFT PRIME) showed benefit of endovascular stroke therapy and were presented and published in 2015 (Table 4)., , , 10, 11 These five studies benefited from the first generation trials by optimizing study design and conduct. However, there were still unanswered questions and limitations to these studies (Table 5).

\section{GUIDELINES, DATA SYNTHESIS AND META-ANALYSES}

In the summer of 2015 the American Hearth Association/American Stroke Association guidelines were updated to reflect changes in the evidence base. The recommendations based on Class I evidence included administration of TPA in eligible patients even if endovascular therapy was considered and administration of endovascular therapy to adult patients with appropriate LVO ischemic stroke presenting within six hours of symptom onset who meet additional clinical and radiological criteria (stroke severity, CT ASPECT score $\geq 6$ ). The recommendations emphasized the preference for second generation devices (stent-retrievers) over intra-arterial tPA. Also strongly recommended was the need for rapid evaluation of stroke patients with non-invasive imaging to determine presence of LVO stroke. 
Table 4 Second generation endovascular RCTs

\begin{tabular}{|c|c|c|c|c|c|c|c|}
\hline Study & $\begin{array}{l}\text { Window } \\
\text { Eligibility } \\
\text { feature }\end{array}$ & $\begin{array}{l}\text { LVO determi- } \\
\text { nation }\end{array}$ & Intervention & Comparison & Outcome & Result & NNTB \\
\hline $\begin{array}{c}\text { MR } \\
\text { CLEAN } \\
2014^{7}\end{array}$ & $\leq 6 \mathrm{hr}$ & $\begin{array}{l}\text { Yes (ICA, } \\
\text { MCA) CTA }\end{array}$ & $\begin{array}{c}\text { Stent-retriever* } \\
\text { +IV tPA }\end{array}$ & IV tPA & $\begin{array}{c}\mathrm{mRS} \text { at } 90 \\
\text { days }\end{array}$ & $\begin{array}{c}\mathrm{n}=500 \\
32.6 \% \text { vs } 19.1 \% \\
\text { OR } 1.67 \text { CI } 1.21 \text { to } 2.3 \\
\text { No difference sICH }\end{array}$ & $\begin{array}{l}7 \text { for mRS } 0-2 \\
3.4 \text { for mRS shift }\end{array}$ \\
\hline $\begin{array}{c}\text { ESCAPE } \\
2015^{8}\end{array}$ & $\begin{array}{c}\leq 12 \mathrm{hr} \\
\text { Multiphase } \\
\text { CTA }\end{array}$ & $\begin{array}{c}\text { Yes (ICA, } \\
\text { MCA) } \\
\text { CTA }\end{array}$ & $\begin{array}{c}\text { Stent-retriever* } \\
\text { +IV tPA }\end{array}$ & IV tPA & $\begin{array}{c}\mathrm{mRS} \text { at } 90 \\
\text { days }\end{array}$ & $\begin{array}{c}\mathrm{n}=316 \\
53.0 \% \text {, vs } 29.3 \% \\
\text { OR 2.6; CI, } 1.7 \text { to } 3.8 ; \mathrm{P}<0.001 \\
\text { Death } 10.4 \% \text { vs } 19 \% \mathrm{p}=0.04 \\
\text { sICH } 3.6 \text { vs } 2.7 \%\end{array}$ & $\begin{array}{l}4 \text { for } \mathrm{mRS} 0-2 \\
3 \text { for } \mathrm{mRS} \text { shift }\end{array}$ \\
\hline $\begin{array}{c}\text { RE- } \\
\text { VASCAT } \\
2015^{9}\end{array}$ & $\begin{array}{c}\leq 8 \mathrm{hr} \\
\text { IV tPA } \\
\text { failure } \\
\text { Or IV tPA } \\
\text { contraindi- } \\
\text { cated }\end{array}$ & $\begin{array}{c}\text { Yes (ICA, } \\
\text { MCA) } \\
\text { CTA }\end{array}$ & $\begin{array}{c}\text { Stent-retriever } \\
\text { +/-IV tPA }\end{array}$ & IV tPA & $\begin{array}{l}\mathrm{mRS} \text { (shift } \\
\text { analysis) at } \\
90 \text { days } \\
\mathrm{mRS}(0-2) \\
\text { at } 90 \text { days }\end{array}$ & $\begin{array}{c}\mathrm{n}=206 \\
\text { OR } 1.7 ; \text { CI } 1.05-2.8 \\
\text { mRS 0-2: } 43.7 \% \text { vs } 28.2 \% \\
\text { sICH } 1.9 \% \text { in both groups } \\
\text { Death } 18.4 \% \text { vs } 15.5 \%\end{array}$ & 7 for $m R S 0-2$ \\
\hline $\begin{array}{c}\text { EXTEND } \\
\text { IA } \\
2015^{10}\end{array}$ & $\begin{array}{l}\leq 4.5 \mathrm{hr} \\
6 \mathrm{hr} \text { IAT } \\
\text { CTP core } \\
<70 \mathrm{ml}\end{array}$ & $\begin{array}{c}\text { Yes (ICA, } \\
\text { MCA) } \\
\text { CTA }\end{array}$ & $\begin{array}{c}\text { Solitaire +IV } \\
\text { tPA }\end{array}$ & IV tPA & $\begin{array}{l}\text { Reperfu- } \\
\text { sion @24 } \\
\text { \& early } \\
\text { neuro Im- } \\
\text { provement }\end{array}$ & $\begin{array}{c}\mathrm{n}=70 \\
\text { Reperfusion: } 100 \% \text { vs } 37 \% \\
\mathrm{p}<0.001 \\
\text { Early improve: } 80 \% \text { vs } 37 \% \\
\text { mRS } 71 \% \text { vs } 40 \% \mathrm{p}=0.01 \\
\text { sICH \& mortality no difference }\end{array}$ & NR \\
\hline $\begin{array}{l}\text { SWIFT } \\
\text { PRIME } \\
2015^{11}\end{array}$ & $\begin{array}{c}\leq 4.5 \mathrm{hr} \\
6 \mathrm{hr} \text { IAT } \\
\text { CTP small } \\
\text { core } 50 \mathrm{ml} \\
(71 \mathrm{pts}) \\
\text { ASPECTS } \\
\geq 6(125 \mathrm{pts})\end{array}$ & $\begin{array}{c}\text { Yes (ICA, } \\
\text { MCA) } \\
\text { CTA }\end{array}$ & $\begin{array}{c}\text { Solitaire +IV } \\
\text { tPA }\end{array}$ & IV tPA & $\begin{array}{c}\text { mRS 0-2 at } \\
90 \text { days }\end{array}$ & $\begin{array}{c}\mathrm{n}=196 \\
60 \% \text { vs } 35 \%, \mathrm{p}<0.001 \\
\text { Mortality } 9 \% \text { vs } 12 \% \\
\text { sICH } 0 \% \text { vs } 3 \%\end{array}$ & 4 for $\mathrm{mRS} 0-2$ \\
\hline
\end{tabular}

*Allowed other devices Abbreviations: CTA- computed tomography angiography; CTP-computed tomography perfusion; ASPECTsAlberta Stroke Program Early CT Score; ICA- internal carotid artery; MCA- middle cerebral artery; IV tPA- intravenous tissue plasminogen activator; mRS- modified ranking scale; sICH- symptomatic intracerebral hemorrhage; NNTB- number needed to treat for benefit; NR- not reported 
Table 5 Strengths and weaknesses of second generation endovascular stroke RCTs

\begin{tabular}{|l|l|}
\hline \multicolumn{1}{|c|}{ Strength } & \multicolumn{1}{c|}{ Weakness } \\
\hline Established class 1 evidence for endovascular & $\begin{array}{l}\text { Most patients treated within 8hrs of symptom onset } \\
\text { (unclear if treatment beyond this is beneficial) }\end{array}$ \\
\hline stroke intervention & Wake up strokes excluded in most studies \\
\hline All primarily used stent-retrievers & Posterior circulation strokes excluded \\
\hline All confirmed presence of LVO & Unclear if CTP is of added benefit within 6 hrs \\
\hline All treated patients quickly & Unclear if CTP is of added benefit after 6hrs \\
\hline Majority used CT/CTA based systems & \\
\hline Established workable time targets & \\
\hline
\end{tabular}

LVO- Large vessel occlusion, CT-computed tomography, CTA-computed tomography angiography, CTP- computed tomography perfusion imaging

After the publication of the guidelines several attempts at data synthesis using traditional meta-analyses and individual patient data (IPD) meta-analysis were conducted. The traditional meta-analysis combined the results from first and second generation trials and demonstrated that the overall result still demonstrated superiority of endovascular therapy compared to best medical therapy in acute ischemic stroke. ${ }^{12}$ Subsequent to this the HERMES clinical trial collaboration pooled the results of the trials in an individual patient data (IPD) meta-analysis to address some of the subgroups who were under-represented in the individual trials (Table 5 ). ${ }^{13}$ The results confirmed the overall superiority of endovascular therapy. Also, the IPD meta-analysis demonstrated substantial efficacy of endovascular therapy within the late $>5$ hour window without an increase in symptomatic intracranial hemorrhage; most of the patients treated late were treated between 5-8 hours. Furthermore, patients who were ineligible for tPA also benefited from endovascular therapy compared with conservative management. Interestingly, the IPD meta-analysis confirmed initial observations from subgroup analysis of the individual trials in that the treatment effect was modified by age. Although the therapy was positive in all age groups, patients who were older than 80 years had an even higher benefit from endovascular therapy.

Last, it is important to note that the overall ef- fect size of endovascular therapy is large. The number needed to treat for benefit (NNTB) for functional independence with endovascular therapy in AIS ranges from 4 in the ESCAPE and SWIFT PRIME trials to 7 in MR CLEAN and REVASCAT. When meaningful improvement in disability (modified Rankin scale shift) was used, the NNTB was 2.6 based on the HERMES meta-analysis. This contrasts with the previous standard of care, intravenous tPA vs. placebo, which had an NNTB to achieve normal functional status of 8-15 depending on the time to treatment delay. A recent study analyzing cost-effectiveness among second generation endovascular RCTs found that adding endovascular treatment to standard stroke therapy such as IV tPA is not only cost-effective but also cost saving. ${ }^{14}$

While stent retriever thrombectomy was the first endovascular technique to show efficacy in pivotal randomized controlled trials of large vessel occlusion stroke, other modern techniques have also been developed. Aspiration thrombectomy using large bore intracranial catheters either alone or in combination with stent retrievers and augmentation of stent retrievers with aspiration via balloon guided catheters have shown promising results in observational studies. ${ }^{15,16}$ The first randomized trial comparing some of these techniques with a novel stent retriever (Penumbra 3D Revascularization Device) has been completed with encouraging preliminary results, suggesting compa- 
rable efficacy of aspiration thrombectomy alone and stent retriever assisted thrombectomy. ${ }^{17}$ We await the final results and critical appraisal of this study and other ongoing studies that may inform device and technique selection for stroke thrombectomy. Expanding the armamentarium available to neurointerventionalists may increase recanalization rates and shorten arterial puncture to recanalization times. It is biologically plausible and consistent with available evidence that should these improvements be realized increased efficacy and safety of mechanical thrombectomy for large vessel occlusion stroke should be possible.

\section{Conclusions}

Several clinical trials, registries, and thousands of treated patients were required to refine the patient selection, device development, stroke response workflow, and clinical trials design. All of this was necessary to establish a firm evidence base for this "new" therapy. However, there are many unanswered questions left: What to do with patients who wake up with stroke symptoms and patients with unknown time of onset? What is the upper limit of the time window? Do we need additional imaging or clinical criteria to select patients at delayed time windows? Should pediatric stroke patients also be included? Is there a role for augmenting the effect of mechanical thrombolysis using medications, such as antithrombotic medications, neuroprotective agents or cell-based therapies? The next generation of endovascular stroke RCTs is already underway to address some of these questions.

Until the results of these next studies are available, current healthcare providers, health system directors, and policy makers have the task of implementing endovascular therapy for all eligible patients to decrease the disability from this disease. This will require restructuring of programs, additional personnel, and system wide coordination. The time is now to deliver the new standard of care.
Author Affiliations: Pavis Laengvejkal, Doungporn Ruthirago, and Parunyou Julayanont are residents in the Department of Neurology at Texas Tech University Health Sciences Center in Lubbock, TX. Yazan Alderazi is an interventional neurologist in that department.

Submitted: $7 / 11 / 2016$

Accepted: 9/4/2016

Reviewers: Subasit Acharji MD

Published electronically: 9/15/2016

Conflict of Interest Disclosures: None

\section{REFERENCES}

1. Furlan A, Higashida R, Wechsler L, Gent M, Rowley H, Kase C, Pessin M, Ahuja A, Callahan F, Clark WM, Silver F, and Rivera F. Intra-arterial prourokinase for acute ischemic stroke. The PROACT II study: a randomized controlled trial. Prolyse in Acute Cerebral Thromboembolism. JAMA 282: 2003-2011, 1999.4.

2. Broderick JP, Palesch YY, Demchuk AM, Yeatts SD, Khatri P, Hill MD, Jauch EC, Jovin TG, Yan B, Silver FL, von Kummer R, Molina CA, Demaerschalk BM, Budzik R, Clark WM, Zaidat OO, Malisch TW, Goyal M, Schonewille WJ, Mazighi M, Engelter ST, Anderson C, Spilker J, Carrozzella J, Ryckborst KJ, Janis LS, Martin RH, Foster LD, Tomsick TA, and Investigators IMSIII. Endovascular therapy after intravenous t-PA versus t-PA alone for stroke. N Engl J Med 368: 893-903, 2013.

3. Kidwell CS, Jahan R, Gornbein J, Alger JR, Nenov V, Ajani Z, Feng L, Meyer BC, Olson S, Schwamm LH, Yoo AJ, Marshall RS, Meyers PM, Yavagal DR, Wintermark M, Guzy J, Starkman S, Saver JL, and Investigators MR RESCUE. A trial of imaging selection and endovascular treatment for ischemic stroke. N Engl J Med 368: 914-923, 2013.

4. Ciccone A, Valvassori L, and Investigators SYNTHESIS. Endovascular treatment for acute ischemic stroke. N Engl J Med 368: 2433-2434, 2013.

5. Saver JL, Jahan R, Levy EI, Jovin TG, Baxter B, Nogueira RG, Clark W, Budzik R, Zaidat OO, and Trialists S. Solitaire flow restoration device versus the Merci Retriever in patients with acute ischaemic stroke (SWIFT): a randomised, parallel-group, non-inferiority trial. Lancet 380: 1241-1249, 2012.

6. Nogueira RG, Lutsep HL, Gupta R, Jovin TG, Albers GW, Walker GA, Liebeskind DS, Smith WS, and Trialists T. Trevo versus Merci retrievers for thrombectomy revascularisation of large vessel occlusions in acute ischaemic stroke (TREVO 2): a randomised trial. Lancet 380: 1231-1240, 2012. 
7. Berkhemer OA, Fransen PS, Beumer D, van den Berg LA, Lingsma HF, Yoo AJ, Schonewille WJ, Vos JA, Nederkoorn PJ, Wermer MJ, van Walderveen MA, Staals J, Hofmeijer J, van Oostayen JA, Lycklama à Nijeholt GJ, Boiten J, Brouwer PA, Emmer BJ, de Bruijn SF, van Dijk LC, Kappelle LJ, Lo RH, van Dijk EJ, de Vries J, de Kort PL, van Rooij WJ, van den Berg JS, van Hasselt BA, Aerden LA, Dallinga RJ, Visser MC, Bot JC, Vroomen PC, Eshghi O, Schreuder TH, Heijboer RJ, Keizer K, Tielbeek AV, den Hertog HM, Gerrits DG, van den Berg-Vos RM, Karas GB, Steyerberg EW, Flach HZ, Marquering HA, Sprengers ME, Jenniskens SF, Beenen LF, van den Berg R, Koudstaal PJ, van Zwam WH, Roos YB, van der Lugt A, van Oostenbrugge RJ, Majoie CB, Dippel DW, and Investigators MR CLEAN. A randomized trial of intraarterial treatment for acute ischemic stroke. N Engl J Med 372: 11-20, 2015.

8. Goyal M, Demchuk AM, Menon BK, Eesa M, Rempel JL, Thornton J, Roy D, Jovin TG, Willinsky RA, Sapkota BL, Dowlatshahi D, Frei DF, Kamal NR, Montanera WJ, Poppe AY, Ryckborst KJ, Silver FL, Shuaib A, Tampieri D, Williams D, Bang OY, Baxter BW, Burns PA, Choe H, Heo JH, Holmstedt CA, Jankowitz B, Kelly M, Linares G, Mandzia JL, Shankar J, Sohn SI, Swartz RH, Barber PA, Coutts SB, Smith EE, Morrish WF, Weill A, Subramaniam S, Mitha AP, Wong JH, Lowerison MW, Sajobi TT, Hill MD, and Investigators ESCAPE Trial. Randomized assessment of rapid endovascular treatment of ischemic stroke. N Engl J Med 372: 1019-1030, 2015.

9. Jovin TG, Chamorro A, Cobo E, de Miquel MA, Molina CA, Rovira A, San Román L, Serena J, Abilleira S, Ribó M, Millán M, Urra X, Cardona P, López-Cancio E, Tomasello A, Castaño C, Blasco J, Aja L, Dorado L, Quesada H, Rubiera M, Hernandez-Pérez M, Goyal M, Demchuk AM, von Kummer R, Gallofré M, Dávalos A, and Investigators REVASCAT Trial. Thrombectomy within 8 hours after symptom onset in ischemic stroke. N Engl J Med 372: 2296-2306, 2015.

10. Campbell BC, Mitchell PJ, Kleinig TJ, Dewey HM, Churilov L, Yassi N, Yan B, Dowling RJ, Parsons MW, Oxley TJ, Wu TY, Brooks M, Simpson MA, Miteff F, Levi CR, Krause M, Harrington TJ, Faulder KC, Steinfort BS, Priglinger M, Ang T, Scroop R, Barber PA, McGuinness B, Wijeratne T, Phan TG, Chong W, Chandra RV, Bladin CF, Badve M, Rice H, de Villiers L, Ma H, Desmond PM, Donnan GA, Davis SM, and Investigators EXTEND-IA. Endovascular therapy for ischemic stroke with perfusion-imaging selection. N Engl J Med 372: 1009-1018, 2015.

11. Saver JL, Goyal M, Bonafe A, Diener HC, Levy EI, Pereira VM, Albers GW, Cognard C, Cohen DJ, Hacke W, Jansen O, Jovin TG, Mattle HP, Nogueira RG, Siddiqui AH, Yavagal DR, Baxter BW, Devlin TG, Lopes DK, Reddy VK, du Mesnil de Rochemont R, Singer OC, Jahan R, and Investigators SWIFT PRIME. Stent-retriever thrombectomy after intravenous t-PA vs. t-PA alone in stroke. N Engl J Med 372: 2285-2295, 2015.
12. Badhiwala JH, Nassiri F, Alhazzani W, Selim MH, Farrokhyar F, Spears J, Kulkarni AV, Singh S, Alqahtani A, Rochwerg B, Alshahrani M, Murty NK, Alhazzani A, Yarascavitch B, Reddy K, Zaidat OO, and Almenawer SA. Endovascular Thrombectomy for Acute Ischemic Stroke: A Meta-analysis. JAMA 314: 1832-1843, 2015.

13. Goyal M, Menon BK, van Zwam WH, Dippel DW, Mitchell PJ, Demchuk AM, Dávalos A, Majoie CB, van der Lugt A, de Miquel MA, Donnan GA, Roos YB, Bonafe A, Jahan R, Diener HC, van den Berg LA, Levy EI, Berkhemer OA, Pereira VM, Rempel J, Millán M, Davis SM, Roy D, Thornton J, Román LS, Ribó M, Beumer D, Stouch B, Brown S, Campbell BC, van Oostenbrugge RJ, Saver JL, Hill MD, Jovin TG, and collaborators HERMES. Endovascular thrombectomy after large-vessel ischaemic stroke: a meta-analysis of individual patient data from five randomised trials. Lancet 387: 1723-1731, 2016.

14. Aronsson M, Persson J, Blomstrand C, Wester P, and Levin L. Cost-effectiveness of endovascular thrombectomy in patients with acute ischemic stroke. Neurology 86: 1053-1059, 2016.

15. Turk AS, Frei D, Fiorella D, Mocco J, Baxter B, Siddiqui A, Spiotta A, Mokin M, Dewan M, Quarfordt S, Battenhouse H, Turner R, Chaudry I. ADAPT FAST study: a direct aspiration first pass technique for acute stroke thrombectomy. J Neurointerv Surg. 2014; 6(4):260-4. doi: 10.1136/neurintsurg-2014-011125 16. Nguyen TN, Malisch T, Castonguay AC, Gupta R, Sun CH, Martin CO, Holloway WE, Mueller-Kronast N, English JD, Linfante I, Dabus G, Marden FA, Bozorgchami H, Xavier A, Rai AT, Froehler MT, Badruddin A, Taqi M, Abraham MG, Janardhan V, Shaltoni H, Novakovic R, Yoo AJ, Abou-Chebl A, Chen PR, Britz GW, Kaushal R, Nanda A, Issa MA, Masoud H, Nogueira RG, Norbash AM, and Zaidat OO. Balloon guide catheter improves revascularization and clinical outcomes with the Solitaire device: analysis of the North American Solitaire Acute Stroke Registry. Stroke 45: 141-145, 2014.

17. Randomized penumbra $3 \mathrm{~d}$ trial of next generation stent retriever meets primary endpoints. In: The Society of NeuroInterventional Surgery (SNIS) 13th Annual Meeting. Boston, Massachusetts, 2016. 